Cuenca, R.H. 1988. Hydrologic balance model using neutron probe data. J. hr. and Drainage Eng. 114(4):644-662.

Doorenbos, J. and W.O. Pruitt. 1977. Guidelines for predicting crop water requirements. FAO Irr. and Drainage Paper 24. FAO, Rome.

Doty, J.A. 1988. Water use of cool season grasses and their effect on grapevine (Vitis vinifera) growth and development. M.S. Thesis, Oregon State Univ.

Feldhake, C. M., R.E. Danielson, and J.D. Butler. 1983. Turfgrass ET. I. Factors influencing rate in urban environments. Agron. J. 75:824830 .
Feldhake, C. M., R.E. Danielson, and J.D. Butler. 1984. Turfgrass ET. H. Responses to deficit irrigation. Agron. J. 76:85-89.

Hardie, W. J. and J. Considine. 1976. Responses of grape to water deficits and stress in particula stages of development. Amer. J. Enol. Viticult. 27:55-61.

Shearman, R.C. 1986. Kentucky bluegrass cultivar ET rates. HortScience 21:455-457.

Sheffer, K. M., J.H. Dunn, and D.D. Minner. 1987. Summer drought response and rooting depth of three cool season turfgrasses. HortScience 22:296-297.

Sullivan, J.T. and V.G. Sprague. 1943. Compo- sition of the roots and stubble of perennial ryegrass following partial defoliation. Plant Physiol. 18:656-670.

Troughton, A. 1957. The underground organs of herbage grasses. Academic, New York.

Van Reuyen, F. C., H.W. Web, and 1. Levin. 1980. The response of grapes to a manipulation of the soil plant atmosphere continuum. I. Growth. yield, and quality response. Agrochemophysica 12:59-68.

Vomocil, J. 1986. Effects of cover crops on availability of water to grapevines in the Willamette Valley in 1985. Wine Advisory Bd. Rpt. 3:811.
HorTSCIENCE 25(5):531-533. 1990

\section{Effects of Morphactin and DCPTA on Stem Growth and Bioinduction of Rubber in Guayule}

\author{
D.A. Dierig and R.A. Backhaus ${ }^{1}$ \\ U.S. Water Conservation Laboratory, U.S. Department of Agriculture, \\ Agricultural Research Service, Phoenix, AZ 85040
}

Additional index words. Parthenium argentatum, bioregulator, chloroflurenol, chloroflurecol, growth regulators

\begin{abstract}
Morphactin applied to stems of guayule (Parthenium argentatum Gray) at rates of 1000 and $5000 \mathrm{ppm}$ caused significant increases in stem diameter over nontreated controls after 120 days. However, rubber content remained unchanged. Additional treatment with DCPTA did not stimulate rubber accumulation in the morphactintreated plants. Morphactin treatments also caused a decrease in plant dry weight. Morphactin and DCPTA in combination appeared to have a negative, synergistic effect on plant growth. Lack of rubber accumulation in morphactin-treated plants was attributed to disorganized, convoluted, vascular cells within the cortical tissue, which is the primary site of rubber accumulation. Chemical names used: methyl-2-chloro-9. hydroxy-fluorene-9-carboxylate (morphactin); 2-(3,4-dichlorophenoxy)-triethylamine (DCPTA).
\end{abstract}

Guayule is a potential source of natural rubber in arid regions of the world. Unlike the rubber tree (Hevea brasiliensis Mull. Arg.), where rubber forms in laticifers, rubber formation in guayule takes place in parenchyma cells of stem cortical tissue (Artschwager, 1943). Maximum rubber yield is the result of a large bark : wood ratio (Artschwager, 1945; Estilai, 1985; Healey et al., 1986). Thus, if the bark, or potential rubber-bearing cells, could be increased in proportion to the wood, or nonrubber-bearing cells, rubber accumulation could possibly be increased.

Received for publication 3 Jan. 1989. From a thesis submitted by D.A.D in partial fulfillment of the requirements for the MS. Trade names and company names are included for the benefit of the reader and do not imply any endorsement or preferential treatment of the product listed by either the authors or the USDA. The cost of publishing this paper was defrayed in part by the payment of page charges. Under postal regulations, this paper therefore must be hereby marked advertisement solely to indicate this fact.

'Professor, Dept. of Botany, Arizona State Univ., Tempe, AZ 85281.
Morphactin has been shown to cause localized swelling of cortex tissue in Monterey pine (Pinus radiata D. Don) when applied topically to the bark (Doss et al., 1977). This bark-banding treatment was originally used as a systemic means of introducing morphactin for growth inhibition in pine and other species (Backhaus et al., 1976). However, the compound caused undesirable swelling due to increased cambial and peridermal activity (Doss et al., 1977).

Rubber synthesis in guayule was reported to be enhanced by treating plants with DCPTA (Yokoyama, 1977; Hayman et al., 1987). Therefore, the purpose of our study was to use morphactin to induce swelling in stems of guayule to increase the bark : wood ratio in an attempt to increase the rubber-forming capacity of the stems. The effect of DCPTA was then tested, alone or following various morphactin treatments, to measure the effectiveness of increasing rubber accumulation in guayule.

The study was conducted in 1982 at the Arizona State Univ. Farm Laboratory, Tempe. Plants were propagated from a bulk seed collection from the guayule breeding program of G. Hansen at the Los Angeles State and county Arboretum, Los Angeles. Plants were transplanted into the field 'at $1 \times 0.36-\mathrm{m}$ spacing and flood irrigated about six times per year. After 2 years of growth, height and stem diameter measurements were taken at 20-day intervals, beginning 1 July, and continued for 120 days. Morphactin was applied 9 July and DCPTA on 30 Sept. Increases in growth over this interval were calculated as a percentage of the initial measurement. Stem diameters were obtained with a micrometer by averaging the widest and narrowest values of the stem at ground level. Plants were harvested after 14 weeks to determine dry weight and rubber content.

To test for enhancement of rubber-bearing cells, six treatments (all per plant) were used: a) nontreated control, b) $1000 \mathrm{ppm}$ morphactin, c) $5000 \mathrm{ppm}$ morphactin, d) 400 ppm DCPTA, e) 1000 ppm morphactin followed by $400 \mathrm{ppm}$ DCPTA, and f) $5000 \mathrm{ppm}$ morphactin followed by $400 \mathrm{ppm}$ DCPTA. Morphactin treatments preceded the DCPTA treatments by 83 days to allow sufficient time for increasing stem diameters. Morphactin solutions were applied according (o the procedures of Backhaus et al. (1976). The compound was supplied from a commercial formulation (Maintain CF 125-U.S. Borax) containing $12.5 \%$ morphactin that was then formulated in a phytobland oil and applied to the bark. Dosage was varied by adjusting the concentration of Maintain CF-125 in culinary Wesson corn oil to make either a 1000or 5000-ppm solution. The morphactin barkbanding solution was prepared by mixing 4 $\mathrm{ml}(5000 \mathrm{ppm})$ or $0.8 \mathrm{ml}(1000 \mathrm{ppm})$ of CF125 with $4 \mathrm{ml}$ of SPAN 80, an emulsifier, and adjusting each to $100 \mathrm{ml}$ with Wesson oil. A plant received $10 \mathrm{ml}$ of this solution applied with a paint brush along the length of the main stem. Shallow cuts through the suberin layer were made before the morphactin application to ensure solution penetration.

DCPTA was obtained from H. Yokayama, USDA/ARS, Pasadena, Calif., and was applied as a foliar spray. Each plant received $25 \mathrm{ml}$ of a 400-ppm solution (Hayman et al., 1987) on 30 Sept., 83 days after morphactin application. Plants were harvested 36 days after DCPTA applications, dried at 50C in a forced-air oven for $48 \mathrm{hr}$, and weighed. Leaves and peduncles were removed before 


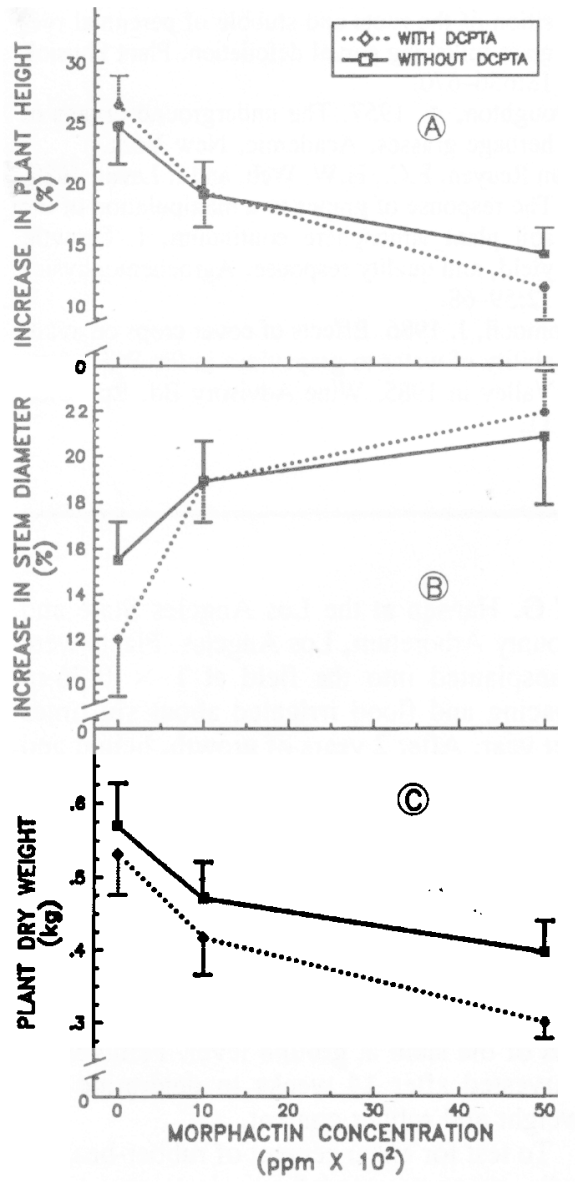

Fig. 1. Influence of morphactin and DCPTA on (A) plant height, (B) stem diameter, and (C) plant dry weight. Treatments include a nontreated control, 1000 and 5000 ppm morphactin, DCPTA only, $1000 \mathrm{ppm}$ morphactin plus DCPTA, and 5000 ppm morphactin plus DCPTA. Each data point is based on 16 observations, and vertical lines represent $\times 1$ sE.

grinding the remaining stem tissue in a Wiley mill to pass a 2-mm mesh screen. Rubber content was determined gravimetrically (Black et al., 1983). Fresh cross sections, 80 to 100 $\mu \mathrm{m}$ thick, from the stem tissue of each treatment were taken and stained for rubber according to the procedures of Addicott (1944) to reveal sites of rubber deposition. The experimental design was a randomized complete block with four plants per treatment and four replications. Data were subjected to analysis of variance procedures.

There was a significant decrease $(P<0.05)$ in plant height associated with an increased morphactin level (Fig. 1A). Plants treated with DCPTA were not significantly different in height from plants not treated with DCPTA at each morphactin concentration. Plant height was affected more by 5000 than $1000 \mathrm{ppm}$ morphactin.A mean height increase of $12 \%$ was noted at this concentration, compared to a mean increase of $26 \%$ in the nontreated controls.

Morphactin treatments increased stem diameter, as reported for other species (Backhaus et al., 1976). Leaf epinasty became apparent in morphactin-treated plants 35 days after bark treatment. Shortly thereafter, an increase in stem diameter was noted, when

A
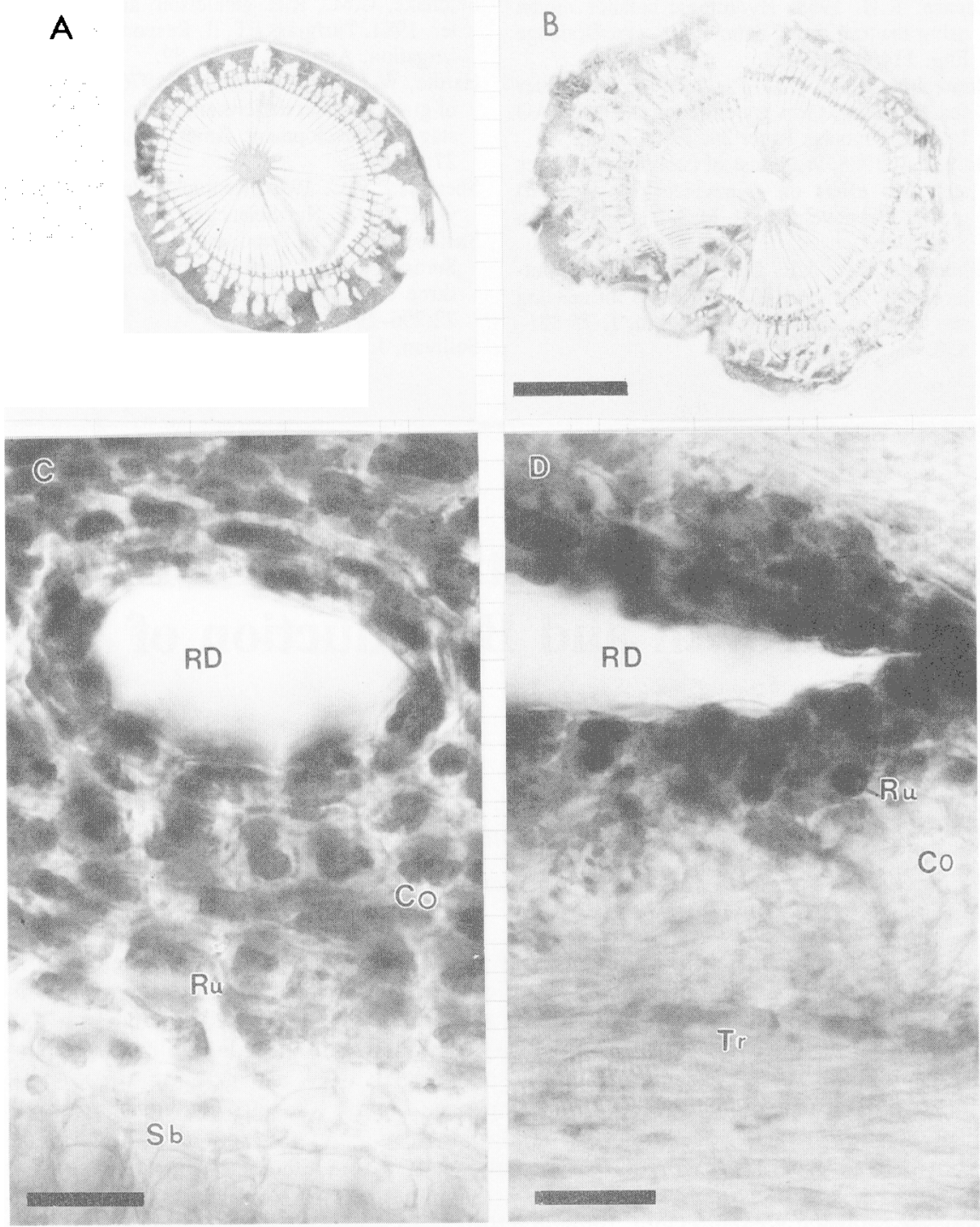

Fig. 2. Photomicrographs of stem cross sections of guayule. (A) Section from a nontreated plant showing normal cortex and cambial development. Dark stained areas are sites of rubber deposition. Horizontal bar $=0.5 \mathrm{~cm}(\times 2.9)$. $($ B $)$ Section from a morphactin-treated stem showing irregular cambium development and nonuniform rubber deposition, while stem diameter has increased, compared to a nontreated stem $(\mathbf{A})$. Horizontal bar $=0.5 \mathrm{~cm}(\times 2.9)$. (C) Close-up of cortical tissue showing normal rubber deposition in a nontreated plant. Note normal cell formation of cortex (Co) surrounding resin duct (RD.). Rubber (Ru) is shown by dark stained areas. The suberin layer ( $\mathrm{Sb}$ ) is not stained. Horizontal bar $=50 \mu \mathrm{m}(\times 320)$.(D) Close-up of cortex tissue in morphactin-treated plant. Note abnormal cell development surrounding the resin duct and the absence of rubber in the cortex tissue. Tracheids $(\mathrm{Tr})$ are also visible. Horizontal bar $=50 \mu \mathrm{m}(\times 320)$.

compared to the nonmorphactin-treated plants. Plants treated with DCPTA were not significantly different in stem diameter from non-, treated plants (Fig. 1B). The most pronounced difference occurred with 5000 ppm morphactin. Visually, the morphactin and nonmorphactin treatments were easily distinguishable by the swollen stems.

Response of plant dry weight to morphactin treatments was similar to the response of plant height (Fig. 1C). Plants treated with 5000 ppm morphactin had a significantly lower dry weight $(P<0.05)$ than the controls. There was no significant effect on plant dry weight between the control and DCPTAonly treatments, or between 1000 ppm morphactin and $1000 \mathrm{ppm}$ morphactin plus DCPTA. However, the 5000-ppm morphac- tin level significantly decreased $(\mathrm{P}<0.05)$ dry weight when plants were also treated with DCPTA, compared to the 5000-ppm morphactin-ordy treatment. Besides growth reduction, phytotoxicity was observed in the form of leaf discoloration and necrosis in plants treated with the higher concentrations of morphactin and DCPTA. Although morphactin-treated stems had larger increases in diameter, growth was stunted, leading to a reduction in plant dry weight.

Rubber content in the morphactin and DCPTA treatments was not significantly different from nontreated plants (data not presented). DCPTA applied alone did not increase plant dry weight or rubber accumulation, when compared to nontreated plants. This result is contrary to the earlier 
report by Yokoyama et al. (1977), where a 2.2- to 6-fold increase in rubber content of young plants was shown. This difference could be due, in part, to the age of plants or the timing of application. Plants used in this experiment had more lignified stems than young, greenhouse-grown plants. To date, there is no convincing evidence that DCPTA significantly increases rubber content in fieldgrown guayule.

Stem cross sections of guayule showed nontreated plants having normal cortex and cambial development, with rubber formation throughout the cortex (Fig. 2A). Cross sections of morphactin-treated guayule stems had irregular cambium development and nonuniform rubber deposition (Fig. 2B). Cortical tissue of a nontreated stem showed uniform rubber deposition surrounding the resin duct (Fig. 2C). Morphactin-treated stems exhibited abnormal cell development surrounding the duct (Fig. 2D). Parenchyma cells differentiated into xylem tissue, which, perhaps, explains the absence of rubber.

Since rubber production depends on the amount of parenchyma tissue, environmental factors may be useful to increase this ratio. For example, timing of irrigation might be used to induce cambial cell divisions that favor this ratio. Girdling may also be a possibility to increase rubber storage in cortex tissues. However, breeding and selection for a high bark : wood ratio may be the best approach.

\section{Literature Cited}

Addicott, F.T. 1944. A differential stain for rubber in guayule. Stain Technol. 19:99-102.

Artschwager, E. 1943. Contributions to the morphology and anatomy of guayule (Parthenium argentatum). USDA Tech. Bul. 842.

Artschwager, E. 1945. Growth studies on guayule (Parthenium argentatum). USDA Tech. Bul. 865.

Backhaus, R. A., R.M. Sachs, and H.F. Hield. 1976. Tree growth inhibition by bark applica- tions of morphactin. HortScicnce 11:578-580. Black, L. T., G.E. Hamerstrand, F.S. Nakayama, and B.A. Rasnick. 1983. Gravimetric analysis for determining resin and rubber content of guayule. Rubber Chem. Technol. 56:367-371.

Doss, R. P., P.M. Neumann, R.A. Backhaus, and R.M. Sachs. 1977. Bark banding of Pinus radiata with morphactin (IT 3456): Influence on trunk anatomy assimilate transport and growth. Physiol. Plant. 39:280-284.

Estilai, A. 1985. Rubber content of bark, bark/ wood ratio, and their significance in developing high rubber yielding guayule plants. Amer. J. Bet. 72:782. (Abstr.)

Hayman, E., H. Yokoyama, and S. Gold. 1987. Guayule cultivar effect on rubber bioinduction. J. Agr. Food Chem. 35:186-188.

Healey, P. L., I.J. Mehta, and A.V. Charlesworth. 1986. Potential rubber carrying capacity (PRCC) in guayule. A structural study. Proc. 4th Intl. Conf. Guayule Res. and Dev., Tucson, Ariz. 16-19 Oct. 1985. p. 293-300.

Yokoyama, H., E.P. Hayman, W.J. Hsu, and S.M. Poling. 1977. Chemical bioinduction of rubber in guayule plant. Science 197:1076-1078.

\section{Competition Between Perennial Ryegrass Sod and 'Chardonnay' Wine Grapes for Mineral Nutrients}

\author{
Siyuan Tan ${ }^{1}$ and Garvin D. Crabtree ${ }^{2}$ \\ Department of Horticulture, Oregon State University, Corvallis, \\ OR 97331
}

Additional index words. Lolium perenne, Vitis vinifera, vegetation management, mowing, nitrogen fertilization

\begin{abstract}
Competition between perennial ryegrass (Lolium perenne L. 'Manhattan II') sod and wine grapes (Vitis vinifera L. 'Chardonnay') for mineral nutrients was investigated with three methods of vineyard floor vegetation management (bare floor, mowed, and unmowed sod) and three rates of urea application $(0,137$, and $274 \mathrm{~kg} \mathrm{~N} / \mathrm{ha})$. Sod decreased $N$ concentration of grape leaves in both 1986 and 1987; Fe concentration in 1986; and $\mathrm{S}, \mathrm{Ca}, \mathrm{B}$, and $\mathrm{Mn}$ in 1987. Sod also reduced total content of all measured nutrients in grape leaves. Mowing did not alleviate this reduction in leaf nutrient content. A high rate of urea $(274 \mathrm{~kg} \mathrm{~N} / \mathrm{ha}$ ) compensated for $\mathrm{N}$ reduction in grape leaves caused by sod competition. Chemical names used: 2 -[1-(ethoxyimino) butyl]-5-[2-(ethylthio)propyl]-3-hydroxy-2 -cyclohexen-1-one (sethoxydim); N,N-diethyl-2-(1-naphthalenyloxy)propanamide (napropamide).
\end{abstract}

Sod management is a common orchard practice (Atkinson and White, 1980; Hogue and Neilson, 1987) that reduces soil erosion, increases soil organic matter and water infiltration into the soil, may improve crop nutrient status, limits weed invasion, and improves traffic and working conditions (Butler, 1986; Hogue and Neilsen, 1987).

Received for publication 22 Feb. 1989. Oregon State Univ. Agr. Expt. Sta. Tech. Paper no. 8800 The cost of publishing this paper was defrayed in part by the payment of page charges. Under postal regulations, this paper therefore must be hereby marked advertisement solely to indicate this fact. 'Graduate Research Assistant.

${ }^{2}$ Professor.
Effective use of sod systems depends on an understanding of competitive interactions, including nutrient interactions, between sod and crop plants (Haynes, 1980; Zimdahl, 1980; Morlat et al., 1984; Skroch and Shribbs, 1986). Competition between sod and tree fruits suggests that $\mathrm{N}$ is of primary importance (Hill, 1962; Lord and Vlach, 1973; Haynes, 1980). Reports on other nutrients are rare and often conflicting (Greenham and White, 1968; Bould et al., 1972; Atkinson and White, 1980; Zimdahl, 1980). Possible methods to reduce the nutrient competition include sod suppression "with chemicals or by mowing, and provision of additional nutrients (Skroch and Shribbs, 1986). In this study, the nutritional and growth changes of grapes were investigated by differing vineyard floor management and by varying the rate of urea fertilization.

Field experiments were conducted during 1986 and 1987 at Oregon State Univ., Corvallis. The vineyard soil was a Chehalis siltyclay loam. 'Manhattan II' perennial ryegrass was sowed in 1983 and the wine grape cultivar Chardonnay was planted in 1984 at a spacing of $1 \times 3.5 \mathrm{~m}$. A randomized complete-block design with two factors and three replications was used. Each replication of each treatment had five vines. Factor one was vineyard floor vegetation management that included interrow sod strip without mowing (unmowed sod), interrow sod strip with mowing (mowed sod), and vineyard floor treated with herbicides (bare floor). The sod between two grape rows in the sod plots was $2.5 \mathrm{~m}$ wide. Factor two was urea fertilization at $\mathrm{O}, 137$, and $274 \mathrm{~kg} \mathrm{~N} / \mathrm{ha}$.

Sethoxydim was sprayed at $0.56 \mathrm{~kg}$ a.i./

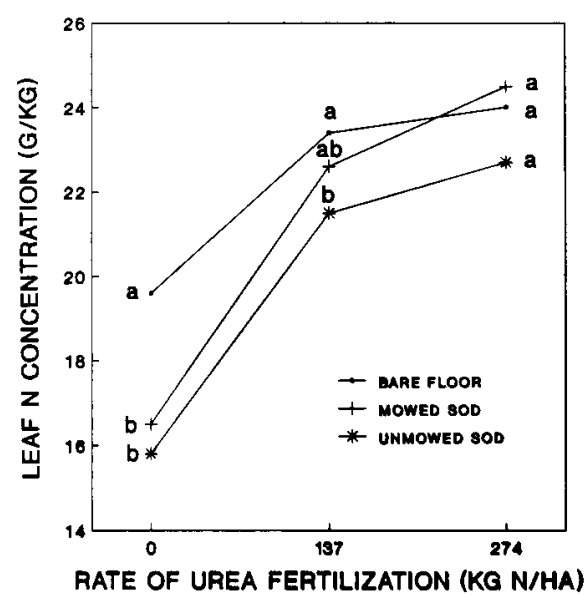

Fig. 1. Leaf $\mathrm{N}$ concentration change of grapes with increasing urea fertilization for three vineyard floor management schemes (1987). Management mean separation by orthogonal contrast tests for each urea rate at $P=0.05$. 